\title{
From Church Scrutinizing the Signs of the Times (GS 4) to Church Discerning (EG 43)
}

\section{Pavel Ambros}

\section{Signs of the times without the light of the Gospel and with the light of the Gospel}

Is contemporary theology a part of the Church scrutinizing the signs of the times? Is the contemporary theologian consecrated to the service of discerning? In Pope Francis' lecture at the Catholic University in Buenos Aires in the form of a video message there very strongly sounds the requirement to overcome the divorce between theology and pastoral care. The decisive moment is the Church's ever stronger awareness of the need to "root, embody, present and interpret faith face-to-face with life". That is the contemporary mission of the Church. Pope Francis demands three things of the present-day theologian: a) to be "first of all a son of his people", which leads him to "acknowledge that the faithful people into which he was born is of theological significance he cannot ignore. He knows that he has been grafted to ecclesial consciousness and immerses himself in those waters; b) "to be faithful", i.e., "to have the experience" and "thinking" of Jesus Christ; c) "to be a prophet", i.e., "to keep alive consciousness of the past as well as the invitation of the coming future".

Here we can sense an echo of what at the very beginning of the Second Vatican Council John XXIII expressed with the term aggiornamento. In his speech of January $25^{\text {th }} 1959$ he used this term to express the need for a reform of the Code of Church Law. ${ }^{2}$ In the same speech he announced the convocation of the Roman Synod and an ecumenical council. The Italian expression he used, which is hard to translate to the official Latin of Church documents or other modern languages, brings a new element into the Church's life. It is not an adaptation of the Church developed in contemporary theories of Christian missions or introduction of new reform steps, but a new pastoral sensitivity to what the present is bringing. There is only one reason: to take into account the "perspective of the good of the souls (bonum animarum) and the closely connected and clearly set line of the new pontificate - the needs of the present moment". ${ }^{3}$

A statement by Pope John XXIII has become well-known: "The Catholic Church is not a museum of antiques. It is like an old spring by a village, which provides water for today's generations, as it

1 FRANCESCO, Il fiume vivo. In un videomessaggio alla facoltà teologica dell'Università cattolica argentina il Papa ricorda il Vaticano II e sottolinea il collegamento dinamico fra tradizione ricevuta e realtà concreta, in: L'Osservatore Romano, (5. 9. 2015 ), p. 8.

2 Cf. JOHN XXIII, Sollemnis allocutio, Acta apostolicae sedis 51/1959, p. 68.

3 Ibid, p. 65. 
did for the previous ones."4 Every day (giorno) brings corresponding duties. Recognizing and accepting these duties, which become morally binding, pastoral imperatives, are that aggiornamento especially when today brings painful situations.

Today the Church is witnessing a crisis underway within society. While humanity is at the threshold of a new age, immensely serious and broad tasks await the Church, as in the most tragic periods of her history. It is a question in fact of bringing the perennial life-giving energies of the Gospel to the modern world, a world that boasts of its technical and scientific conquests but also bears the effects of a temporal order that some have wanted to reorganize by excluding God. ${ }^{5}$

All that causes sadness and anxiety is part of the life of Christ's disciples from the very beginning and is linked to Jesus's person and the life of the early Church. John XXIII goes on:

These painful considerations remind us of the duty to be vigilant and keep our sense of responsibility awake. While distrustful souls see nothing but darkness falling upon the face of the earth, we prefer to restate our confidence in our Savior, who has not left the world he redeemed. Indeed, making our own Jesus' recommendation that we learn to discern "the signs of the times" (Mt 16:4), it seems to us that we can make out, in the midst of so much darkness, more than a few indications that enable us to have hope for the fate of the Church and of humanity. ${ }^{6}$

John XXIII's basic intuition is imprinted into another expression - $i$ segni dei tempi (signs of the times). The Pope bases his trust on the biblical reference from Mathew's gospel: "You know how to interpret the appearance of the sky, yet you can't interpret the signs of the times?" (Mt16:3b), from which he then deduces God's perpetual guarding over history and the human lot. As Marie-Dominique Chenu $(\dagger 1990)$ notes, the term signs of the times entered colloquial speech when the encyclical Pacem in terris was published on April $11^{\text {th }}, 1963$. The encyclical significantly influenced the preparatory works on Schema XVII, of which the pastoral constitution Gaudium et spes was born. It was even seriously considered that this encyclical could be adopted without changes or presented as the basis of the Council's negotiations. ${ }^{7}$ In the official Latin original the expression signs of the times did not appear at all. In the Italian version it appeared four times, always as an indication of the positive direction of human society. ${ }^{8}$ The expression itself came to bear a programmatic content. It enters the field of theology anew as an action arising from moral analysis of the situation which turns the human being to an intrinsically binding action. It gives a new perspective to action, practice and human decision-making. ${ }^{9} \mathrm{~A}$ new sensitivity and understanding of the practice of the Church is born. ${ }^{10}$

4 II. Vatikánský koncil, Ř́m: Křestanská akademie, 1966, p. 31

JOHN XXIII, Humanae salutis 3, Acta apostolicae sedis 54/1962, p. 6.

Ibid, 4, p. 7.

Cf. Karel SKALICKÝ, Radost a naděje, Řím: Křestanská akademie, 1968, p. 40, note 2

Cf. Marie-Dominique CHENU, Les signes des temps, Nouvelle Revue Théologique 87/1965, p. 30, note 2.

Cf. ibid, pp. 29-30.

10 Priests "must willingly listen to the laity, consider their wants in a fraternal spirit, recognize their experience and competence in the different areas of human activity, so that together with them they will be able to recognize the signs of the times. While trying the spirits to see if they be of God, priests should uncover with a sense of faith, acknowledge with joy and foster with diligence the various humble and exalted charisms of the laity." (Presbyterorum ordinis 9); "Among the signs of our times, the irresistibly increasing sense of the solidarity of all peoples is especially noteworthy. It is a function of the lay apostolate sedulously to promote this awareness and to transform it into a sincere and genuine love of brotherhood" (Apostolicam actuositatem 9); "The Sacred Council exhorts all the Catholic faithful to recognize the signs of the times and to take an active and intelligent part in the work of ecumenism" (Unitatis 
Paul VI links the two terms: aggiornamento and signs of the times are a program seeking forms of pastoral activity that correspond to the state of the contemporary human and can be accepted by him. But that does not consist in a "laudable endeavor to come closer to the masses and to particular groups", with the aim of "becoming like them rather than different from them and by this worthless imitation forfeit the real value and effectiveness of the endeavors". The hard-to-realize statement "to be in this world, not of this world" also holds for it. ${ }^{11}$ All the stronger there sounds the promise sealed by Christ's prayer to Father for us: "I'm not asking you to take them out of the world but to protect them from the evil one" (John 17:15). Despite this 'risk' Paul VI presents aggiornamento as "a guiding principle", "a stimulus to the Church to increase its ever growing vitality". ${ }^{12}$ Aggiornamento is an impetus for the Church, a stimulus to "its ability ... to give careful consideration to the signs of the times, always and everywhere 'proving all things and holding fast that which is good' (1Thess 5:21) with the enthusiasm of youth".13

The Council asked not only what the Church is ad intra, how it understands itself, but what its situation in the world is and especially how it can be effectively present ad extra. ${ }^{14}$ Angelo Giuseppe Roncalli united his life experience in this unifying view of the Catholic Church ad intra and ad extra. One year after he was consecrated he became the personal secretary of the Bergam bishop Giacomo Radini-Tedeschi († 1914), engaged in the Catholic social movement that later recast itself as Catholic Action. For a short time he was accused of modernism. ${ }^{15}$ After his death he shortly taught Church history, then when WWI broke out he lived through the horrors of war as a medical worker in the army. Similarly important was the experience of papal legate in Bulgaria (1925-1933) and Turkey and Greece (1934-1944). What Rome means from the point of view of Constantinople became for him another field that he placed at the centre of the Council's attention. This position of searching for the situation of the Church ad intra and ad extra brought him to the world in which the Church lives the fertile and dramatic tension of joy and pain, hope and anxiety. The experience of war and post-war France, including his personal interventions for the benefit of Jews from Slovakia and Bulgaria, ${ }^{16}$ only served to multiply his view of the world. In the spirit of the Italian Rosmin tradition he on the one hand aw the five wounds of the crucified Christ in imperialism, Marxism, progressive democracy, freemasonry and secularism, and on the other hand the possibility of renewal through pastoral engagement. His view of the signs of the times comprised of realized eschatological Christianity without the accompanying comfortless apocalyptic. ${ }^{17}$ But the signs of the times could not be merely a renewed version of the Roman vox temporis, vox Dei, but a Christian search for a balanced view between extreme Eurocentrism, global scepticism and false or overt uncritical fascination with the optimism of the world..$^{18}$ According to Bernard Häring "optimism to the world can be false and dangerous, if it is not accompanied by yet another orientation, the spirit of poverty and asceticism". ${ }^{19}$

redintegratio 4$)$.

11 PAUL VI, Ecclesiam suam, 49.

12 Ibid, 50.

13 Ibid.

14 Cf. Charles MOELLER, Pastoralkonstitution über die Kirche in der Welt von heute, in: Lexikon für Theologie und Kirche. Das zweite vatikanische Konzil. Konstitutionen, Dekrete und Erklärungen, Freiburg - Basel - Wien: Herder, 1968, p. 247.

15 Cf. Fausto FONZI, I cattolici e la società italiana dopo l'Unità, Roma: Studium, 1953, pp. 90-115.

16 Cf. La Fondazione Wallenberg certificherà l'aiuto di Giovanni XXIII agliebrei, Zenit. Il mondo visto da Roma (on-line), at: http://www. zenit.org/it/articles/la-fondazione-wallenberg-certifichera-l-aiuto-di-giovanni-xxiii-agli-ebrei, retrieved November $20^{\text {th }}, 2015$.

17 Cf. GIOVANNI XXIII, Scritti e discorsi 1953-1958, 2, Roma: Edizioni paoline, 1959-1962, pp. 28-42.

18 Cf. Evangelista VILANUOVA, Intersession (1963-1964), in: The History of Vatican II. Vol. III: The mature council. Second period and intersession (September 1963 - September 1964), eds. Giuseppe ALBERIGO - Joseph A. KOMONCHAK, New York - Leuven: Orbis Peeters, Maryknoll, 2000, pp. 410-413.

19 Ibid, p. 410 (quote of B. Häring). 
The Swiss Calvinist theologian Lukas Vischer († 2008), representing the World Council of Churches, brought an important shift to the preparation of the Scheme. He pointed out the importance of the concept signa temporum (signs of the times) as the key to interpreting the entire subsequent text. The notion of time as sign and voice is problematic in that it does not show how God speaks through them. He asks how to distinguish the voice of God from a deceiving voice. From the biblical point of view time is an ambiguous phenomenon and interpretations of the history of salvation constantly point to it. Jesus himself rejects a simplified reading of divine providence, as shown in his dispute with contemporaries (Luke 11:29-32). In a similar spirit Pope Francis speaks of the difference between Jonah's syndrome and Jonah's sign. ${ }^{20}$ Vischer showed that the Scheme completely omitted the eschatological aspect of the signs of the times. That is why he proposed an improvement and extension, because "it offers a too innocent view of the world and therefore cannot mediate true hope to the world". ${ }^{21}$ Josef Ratzinger briefly summarizes the discussion in his commentary when speaking about the associated hermeneutic question, namely how to com-

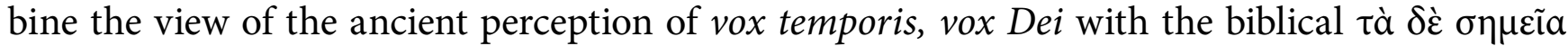
$\tau \tilde{\omega} v$ kaı $\rho \tilde{\omega} v$ (signs of the times; Mt 16:3) while maintaining an exegetically responsible exegesis of Jesus's eschatological warning to those who do not discern the signs of the times. "Is not Christ himself as the true sign of the times a contradiction to accounting for time (chronos) as sounded by the words vox temporis?"22 This gaping abyss of Christian and non-Christian perception of joy and anxiety, hope and sorrow is treated in the final version of the scheme by the supplement to discern and interpret the signs of the times in light of the gospel. The kerygmatic character of the text relies on a reference to wisdom which knows that "the spirit of the Lord fills the world and the one who holds everything together knows every word said" (Wis 1:7). In this sense the Church discovers this time as kairos, which must at the same time be dia-krisis of those from whose hearts the veil has been removed (2 Cor 3:14). The opposite are those whose "minds were hardened, for to this day the veil is still there when the Old Covenant is read and it is not disclosed to them that it ends in Christ" (2 Cor 3:14) ${ }^{23}$ The text goes radically further when it assumes John XXIII's most proper charismatic vision: "All this holds true not only for Christians, but for all men of good will in whose hearts grace works in an unseen way." ${ }^{24}$ Here is born that beginning of a beginning reminding us of Elijah journeying through the open desert to reach God's mountain. "If we - tired, torpid and downcast- rested under the vine plant of Council triumphalism," Rahner says in his lecture of December $12^{\text {th }} 1965$, five days after the Council's conclusion, "the angel of the Lord will be able to or will have to wake us from our slumber by means of terrifying dangers and hardships of this time, through persecution, apostasy and pain of the heart and spirit; rise up, the greater part of the journey is yet before us." ${ }^{25}$ Since the Council the Church is sailing on board one ship with humanity, with which it takes the veil from the eyes to human hopes and anxieties, let us add with humans "buffeted between hope and anxiety". ${ }^{26}$

20 Cf. FRANCIS, La sindrome di Giona, L'Osservatore Romano 153/236 (15. 10. 2013), p. 7.

21 Nach der dritten Session des zweiten Vatikanischen Konzils, Reformatio2/1965, pp. 78-88.

22 Joseph RATZINGER, Ersten Kapitel des ersten Teils, in: Lexikon für Theologie und Kirche. Das zweite vatikanische Konzil. Konstituonen, Dekrete und Erklärungen, Freiburg - Basel - Wien: Herder, 1968, p. 313.

23 Ibid, p. 314.

24 Pastoral constitution Gaudium et spes 22. Further, only GS and section number.

25 Karl RAHNER, Das Konzil - ein neuer Beginn, Freiburg - Basel - Wien: Herder 1966, pp. 21-22.

26 GS 4. 


\title{
2. Onboard a ship with people buffeted between hope and anxiety
}

This paper does not aim at a historico-theological reconstruction of the broad debate on the topic of signs of the times. Nor can it deal with the similarly rich reception of the Council text. We will rather listen to one particular repercussion of the tradition induced with the image of Noah's ark. One of the statements accompanying the Council discussion on Scheme XIII entitled De ecclesia in mundo huius temporis labelled the scheme "as a Noah's ark into which all issues that could not be placed elsewhere were temporarily located". ${ }^{27}$ The image itself probably wanted to express something quite different, but it pointed to the nature of the discussion. ${ }^{28}$ The tension between the prevailing optimism and programmatic dialectical approach shows one hidden paradox of the text: its different sociological and theological emphases. The resulting text was not an integration of the two approaches, but a reached agreement, assuming a juxtaposition. ${ }^{29}$ It shares the cultural atmosphere of the fading-away modern period:

\begin{abstract}
"To a certain extent, the human intellect is also broadening its dominion over time: over the past by means of historical knowledge; over the future, by the art of projecting and by planning. Advances in biology, psychology, and the social sciences not only bring men hope of improved self-knowledge; in conjunction with technical methods, they are helping men exert direct influence on the life of social groups. At the same time, the human race is giving steadily-increasing thought to forecasting and regulating its own population growth." ${ }^{30}$
\end{abstract}

This positive view of the world is no novelty. Christians have always had to face a world full of enemy attitudes. The stories of martyrs and worshippers witness to God's power in history, but also to cowardice or lack of freedom to adhere to Christ. The Church also knows stories of weakness, the shame of Christian sinfulness. Similarly it has faced with greater or lesser success the risk of corruption with the powerful of this world. Even here the history of the Church wrote its light and shady, shameful and shame-hurting events. Nonetheless, the goal of Christian life is to transform time, to capture the eternal in the transitory, "since eternity is not something but someone, or better, it is the eternal love of three Persons". ${ }^{31}$ Death does not speak the last word. For time is seeking and finding what man has lost. To summarize with the words of Ignatij Brjantschaninov: "God's decisions are present and effective in the midst of what humans and demons do, like a subtle spirit in the midst of being, independent of beings, unlimited by beings, affecting beings and unaffected by them."'32

"The Church is very soon conscious of its existence as a theological datum, which manifests itself in self-reflection." ${ }^{\prime 3}$ The notion of the Church as a great ship to which care of our eternal salvation is entrusted is part of the theology of the Church Fathers. "The Church is a passage by sea to portus salutis. The Church is a dangerous and at the same time magnificent pilgrimage: it is full of danger, for it has not yet reached the ultimate haven, and magnificent, for it represents the

27 Charles MOELLER, Pastoralkonstitution über die Kirche in der Welt von heute, p. 261.

28 Cf. Karel SKALICKÝ, Radost a naděje, pp. 57-58.

29 Cf. Evangelista VILANUOVA, Intersession (1963-1964), p. 403.

30 GS 5.

31 Olivier CLÉMENT, Transfigurer le Temps. Notes sur le temps à la lumière de la tradition orthodoxe, Paris: Communauté de Taizé Delachaux et Niestlé, 1959, p. 99.

32 Ignatij BRJANTSCHANINOV, Сочинения, vol. 2, Аскетические опыты, С.-Петербург, 1886, p. 83.

33 Jean DANIÉLOU, Théologie du Judéo-Christianisme, Paris: Desclée, 1958, p. 317. 
only place of inherent security amidst the evil sea." ${ }^{34}$ Martin Luther still transmits a view of the Church based on the dogmatic conviction that the faithless world can be "saved in the holy ark of Christianity, providing a safe, dry place for it". ${ }^{35}$ The critic of Christianity and sceptic Celsus in his polemic with Origen spoke mockingly of the "miraculous box concealing everything". ${ }^{66}$ The Church represents an ark in which the family of the saved survives the world flood and it will also survive the last judgment, as it had survived the great water of Noah's ark that became salutary for it.

The image of the Church as a ship that provides safety to people buffeted between hope and anxiety thus became an expression of the cultural, enculturated Christianity of the first and second millennium. From the point of view of Gregory of Nyssa the world is "an immense sea of Divine decrees" ${ }^{\prime 37}$ that man must learn to read in order to reach his end. The irresolution of man is his lot, which he must face with the novelty of man renewed in Christ. In their kerygmatic orientation the Church Fathers turn to men of their times and recall the lot of Ulysses, who let himself be chained to the mast of his ship in order to resist the seduction of the Sirens. It is a world which in the view of Pope Innocence III is a "bitter sea" "filled with the sweet lure of the Sirens". ${ }^{38}$

The birth of Christ from the heart of the Church and the faithful is the reason for the closeness of the safety of the voyage through life. Of the grace of Baptism Christ is born through the Church in our hearts, whereby this birth takes place again and again in a life ever more filled with grace. Anima ecclesiastica, as Origen said, forms the face of the Church that is likened to Christ. In the words of Hugo Rahner:

This teaching thus enters into closest proximity with the conception of Church as virgin mother and mediatrix of salvation, in the newly created life of baptismal grace likened to Christ. But the doctrine of birth of God from the Church and the heart of the faithful does not derive the beginning of the grace-filled unity in Christ as much from the individual grace-endowed human being and his participation in the Body of Christ, but rather from the single Christ who has the same likeness in all and brings all together in the unity of his Body, which is the Church. ${ }^{39}$

This likeness of the Church reflecting itself, its life in the world and its mission in it is present like a leitmotif. This view of Christ belonging to the world became the basic perspective of the ecclesiology of the first millennium as well as the High Middle Ages. Minucius Felix sees Christ's cross in military flags, banners and standards: "Your victorious trophies have not only the likeness of a simple cross, but also of man hanging on it." ${ }^{30}$ But the very fact of the Church's presence is not without risk. Only one not immersed in the bitterness of the world can set sail on the bitterness of the sea which is the world. In words accompanying educated people throughout the Middle ages: "Nay, get ye gone, ye sirens, whose sweetness lasteth not; leave him for my muses to tend and heal."

34 Hugo RAHNER, Symbole der Kirche, Salzburg: Otto Müller Verlag, 1964, p. 240.

35 Quoted according to Per LUNDBER, La Typologie baptismale dans l'ancienne Église, Leipzig: Alfred Lorentz, 1942, p. 1, note 1.

36 ORIGEN, Adversus Celsum, IV, 41.

37 GREGORY OF NYSSA, In Canticum canticorum homiliae, 12, in: PG44, 1016b.

38 INNOCENC III, Sermo 22, in: PL 217, 555; Sermo 6, in: PL 217, 617c.

39 Hugo RAHNER, Symbole der Kirche, pp. 13-14.

40 Markus Minucius FELIX, Octavius, 29, 8.

41 BOËTHIUS, Consolation of Philosophy, 1, 1, 11. 
Since the second century AD Justin's basic dogmatic idea is repeated, facing the ancient Greeks' ever present anxious whisper of "the bitter sea": "For the sea is not traversed except that trophy which is called a sail abide safe in the ship; ... and this shows no other form than that of the cross." ${ }^{2}$ The German pilgrim overcomes the dangers of his pilgrimage to Jerusalem with the words of Ezza's song: "Our victorious cross of the Saviour, our desire for the homeland goes up to the heavens." ${ }^{33}$ And Dante does not hesitate to express both, anxiety and hope:

Who enters with me, let him acquit of hope! ${ }^{44}$

Oh you who, desirous to listen, in your small boat followed my ship, which sails on singing. ${ }^{45}$

Similarly Goethe's Faust through the mouth of Mephistopheles preconceives the anxiety of the modern period when he says of man:

He would live a lot better if he knew not of the heavenly glow; he calls it reason, by which he means that he can be more beastly than the beasts. ${ }^{46}$

Similarly he captures hope sung by a chorus of female penitents:

A mere simile are

Earthly events;

What is transitory

Changes to deed here;

What cannot be described

Is already being here;

To eternal womanhood

We are carried up. ${ }^{47}$

In this small overview we are presented with an image of perceiving the world in which man was a subject in the spirit of the Christian-Enlightenment tradition. He struggled for his self-consciousness by seeking a path between hope and anxiety in his presence, and thereby created a culture in relation to something else, tore himself out of the datum and momentum of the time.

In our Czech milieu we had the opportunity to experience the last rise of this civilizational epoch of life between hope and anxiety in the 1960s, when Ludvík Vaculík showed a new form of experiencing hope and anxiety as signs of the times with his appearance at the Writers' Congress in 1967. It dealt with the dignity of the socialist human who experienced the lack of meaningfulness of life as the decline of an ideologically trustworthy communist totality in two ways: a) power was monopolized by the governing communist nomenclature (today we would say oligarchy), which knew nothing but careerism, cliché and phrases; b) life in socialism was experienced as a farce of the revolutionary movement and meaninglessness of the system, which forced honest commu-

42 JUSTIN, Apology, I, 55,3.4.

43 Christoph LANGE, Das Ezzo-Lied in der VorauerÜberlieferung. Text, Übersetzung und Kommentar, München: AVM- Akademische Verlagsgemeinschaft, 2014.

44 Dante ALIGHIERI, Divine Comedy, Hell III, 9, Praha: J. Otto, 1930.

45 Dante ALIGHIERI, Divine Comedy, Paradise II, 1-3, Praha: J. Otto, 1930.

46 Johann Wolfgang GOETHE, Prologue in heaven, in: Faust, Praha: Academia, 2006, p. 36.

47 Johann Wolfgang GOETHE, Mountain ravines, in: Faust, p. 424. 
nists to cheat or deny themselves by telling anti-regime jokes among the comrades. The sign of the time became meaningful speech. Vaculík said:

And I want to return to what I think of the character of every power: that its development and behaviour is governed by its intrinsic laws, which cannot be changed by the person in power, nor the class in power, since it is simply the laws of human behaviour in a certain situation: in power. The first law of every power is that it wants to continue being. It reproduces itself in ever more precise form. Second, it becomes ever more homogeneous, purifies itself of the heterogeneous, until each of its parts is an image of the power as a whole. (...) The intrinsic law of power prefers people who are internally organized as it is. But because there is a lack of them it must use other people, whom it adjusts according to its need: it blackmails them.

Power is a peculiar human phenomenon which is due to the fact that already in the woodland band someone must issue orders and that even in the company of only noble spirits someone must summarize what has been learnt from the discussion and formulate the necessity. Power is a specifically human situation. It affects the ruling and the ruled and poses a risk to the health of both. Thousands of years of experience with power have led humanity to try to set some working rules. ${ }^{48}$

The sign of the time how to find a particular path determined by the polarity of hope-anxiety became the working rules of power. This fascination by meaningfulness became the driving force of the political events and culture of the 1968 Prague Spring. In the words of Milan Kundera "not only to guard the borders, but also to superordinate epochal interests to momentary interests". When we go to see this sign of the time in the museum of post-communism, we find that most visitors view recent history as meaningless images. They became part of the "end of the world" where man struggled between hope and anxiety. And who, it seems, is doomed to damnatio memoriae. Not infrequently, when we enter the debate of contemporary protagonists of post-culture, there remains in us a certain strong touch of cold: almost as if the contemporary scholar 'had to' speak in some nocturnal solitude of reason left to itself, which feeds since sunrise on the terrible cry of Nietzsche's madman:

I seek god, seek god! (...) Is there still some Up and Down? Are we not wandering through endless nothingness? Have we not been fanned by empty space? Has it not got cold? Does not night set all the time, ever more nights? Must we not light the lanterns already before noon? Have we not yet heard the noise of the gravediggers burying god? Have we not yet smelled the odour of divine decay? - Even the gods are decaying! God is dead! God will stay dead! And we have killed him! What shall we comfort ourselves with, we murderers of all murderers? (...) It is also told that on that same day the madman intruded into various churches and there sang his Requiem aeternam deo. When they led him out and interrogated, he kept answering: 'What are these churches, if not the tombs and gravestones of God? ${ }^{49}$

48 ○ Ludvík VACULÍK, Projev na IV. Sjezdu Svazu československých spisovatelů, Praha 27.-29. června 1967, in: Ludvík Vaculík (online), at: http://www.ludvikvaculik.cz/index.php?pid=56\&sid=36, retrieved November $15^{\text {th }} 2015$.

49 Friedrich NIETZSCHE, Der tolle Mensch, in: Die fröhliche Wissenschaft 125 (online), at: http://gutenberg.spiegel.de/buch/-3245/6, retrieved November $1^{\text {st }}, 2015$. 
Hence stems the ever returning question: Can I as a contemporary Christian / contemporary theologian attempt to understand the dramatic and disconcerting fury we call "contemporary Europe", its culture, as a sign of the time? Yes, precisely because it concerns me personally? It is not a matter of academic understanding, but of situating the Christian life in the environment of which St John Paul II spoke in the seat of the European Economic Community in Brussels (May 20 $0^{\text {th }}$ 1985), not concealing the heavy shadows covering Europe. According to him, the progress of humanity - carried along by unprecedented expansion of human activity based on the rationality of science and technology and setting through of values of equality and freedom - issued in a situation when "the rationalistic optimism which his conquests inspire lead man to the negation of every transcendent ideal which escapes the dominion of his own genius. (...)He asks for freedom and flees responsibility; he aspires to wealth and fails to wipe out the poverty next door; he professes the equality of all and too often gives in to racial intolerance. In spite of all that he claims for himself, and all that is actually accessible to him, contemporary man is tempted by doubt regarding the meaning of life, by anguish and by nihilism." 50

Thirty years later Pope Francis at the same place - in the European Parliament - could not speak otherwise:

If everyone's right is not harmoniously ordered to a broader good, it ultimately regards itself as unlimited and becomes a source of conflicts and violence. (...) The human being risks being reduced to the mere wheelwork of some mechanism, which deals with it as with some utile consumer good, so that - as we unfortunately often see - once her life does not fulfil its function in this mechanism, it is without overt constraints discarded as in the case of the ill in the terminal stage, deserted and unprovided for old people or children killed before birth. ${ }^{51}$

We find a difference between the sea of bitterness of the ancient world and the irrational greed of our civilization in a different perception of the present. When a monk in sixth century AD wanted to reason out why he should plunge into the monastery that had been set on fire by barbarians and together with monastic rules and liturgical books rescue the writings of ancient heathen philosophers, he found reason in the hope that he is saving the future world. If the contemporary Christian is to make a similar gesture, he faces the decision to turn off the online "babbling" of which no one knows anymore what it is really about. It floods us in a stream of minute-long portions of news from Syria, from the life of pets or a political scandal, not allowing us to perceive the particular form of the contemporary deficiency. But what will happen if a blackout of our online connection with the so-called present occurs? This present was not begotten by the contemporary young generation, but by the generation of their parents. The lethal boomerang of time became a generational abyss and a new, as yet unfilled emptiness.

\section{Discerning as a path to hope?}

Pope Francis, who has come from the periphery of the Catholic Church to its very centre, has brought a sharp vision, an idiosyncratic style of speech, Ignatian imagery and a primary emphasis on the role of the Pope as bishop of the city of Rome who presides with love to the whole Church.

50 JOHN PAUL II., Alla sede della Comunità economica europea, in: Holy See (online), at: http://w2.vatican.va/content/john-paul-ii/it/ speeches/1985/may/documents/hf_jp-ii_spe_19850520_european-comm-bruxelles.html, retrieved November $14^{\text {th }}, 2015$.

51 FRANCIS, Come ridare speranza al futuro, L'Osservatore Romano 270 (26. 11. 2014), p. 1. 
The independence of his theological reflection and natural intelligence rely on life experience and intellectual formation, which is not based, one-sided, only on academic training. But foremost, in the course of his life he has gained a great knowledge of human action. He was culturally and conceptually educated in the environment of liberation theology. He adopted it first of all in the form of personal folk piety. Repeated claims of his dogmatic conservativeness depend on how one defines liberation theology. As he does not have much need to deal with extraordinary things, he takes a reserved attitude - in his own words - to utopian laboratories, humanist utopias substituting for the Kingdom of God, as well as to institutional formalism or other religious clichés. He subsumed all that under the strong, patristic-inspired term of the Church as holy harlot. ${ }^{52}$ What he is really deeply troubled by is the mysterium iniquitatis in the midst of the human community, especially the poor. ${ }^{53}$

On his arrival to Europe he was confronted with the fading away of the civilisation epoch of life between hope and anxiety. The dimming of light touches also the European local churches. Fatigue, feebleness and lack of agility are the main indicators of ecclesial institutionalized sloth and fundamental unfaithfulness which bears the terrible label: ecclesial atheism. But already in his text The Bad Superior (1983) Bergoglio spoke of good and bad tiredness: good tiredness is "the tiredness that leaves you tired but happy: after a hard day's faithful work, you are brought to the Blessed Sacrament once again to intercede for your sheep - sheep of whom you are not ashamed, sheep for whom you go in to bat with the Lord." 54 The Pope discerns at the level of life in which he opens himself up to its meaning.

The Spirit renews its life by discerning. By discerning it gives the form of life to dry bones. Through discerning the contemporary Christian perceives what brings inner comfort as well as what brings man to unrest. The unrest of searching, discerning, insight, all that leads the Christian to practical decision-making. It is typical for Bergoglio that he does not see a dramatic difference between what we perceive in our life as the all-constituting initiative on God's part and what we perceive on our part as exhausting exertion for daily vigilance and faithfulness. For lack of comfort makes us "lukewarm, lazy and careless, (...) and we lose spiritual comfort by our own fault" ${ }^{55}$ In that we ought to be aware that "it is not in our power to attain and maintain deep piety, burning love, tears or any spiritual comfort, but it is all the gift and grace of God". ${ }^{56}$ For Bergoglio decision-making is only possible when discerning is understood as ascetic effort and exertion that makes our availability grow and at the same time contains a high level of flexibility in action. At the same time there still remains space we cannot fully control. But the essential thing Bergoglio's witness brings is the far-reaching finding: the European cultural tradition of practical wisdom (fronesis) and the Christian discerning of spirits can after all in contemporary globalization face superficiality, banalization and media shortcut.

Can it open up a path through the hope and anxiety of the present otherwise than via discerning, purification and reform? Scrutinizing the signs of the times and interpreting them in light of the

52 Cf. Leonardo BOFF, Francis of Rome and Francis of Assisi: A New Springtime for the Church, New York: Orbis Books, Maryknoll, 2014, pp. 32-45. According to St. Ambrose the two words are an oxymoron: The Church is holy (casta), but the expression harlot (meretrix) is a title that does not disparage the Church. Both expressions point to the nature of the Church: She maintains purity and at the same time the willingness to receive all.

53 Cf. Philip ENDEAN, Writings on Jesuit Spirituality by Jorge Mario Bergoglio, S.J., Studies in the Spirituality of Jesuits 3/2013, p. 7.

54 Jorge Mario BERGOGLIO, The Bad Superior, in: Studies in the Spirituality of Jesuits 4/2013, p. 33.

55 IGNATIUS OF LOYOLA, Spiritual Excercises, 322.

56 Ibid. 
Gospel expresses the relationship between world and Church anew. Theologically a new sensitivity opens up here as pastoral cosmology, based on Creation. Scrutinizing signs of the times leads to knowledge of the Father who accompanies man through history. Thus founded pastoral anthropology develops the relationship of grace and nature. The main object of interest is the presence of the Creator-Father in the created world, whether as a datum or as freedom experienced in the Church. Pastoral discerning has a different starting point: it is the presence of Christ as beginning and culmination of the salvation poured out into the entire body of Christ, i.e., the Church. Its topic is the post-Easter presence of Christ in the Church as a humanly perceivable, experienced and spiritual fertility developing the unity of the divine and the human. Signs of the times are the pneumatological dimension of the life and mission of the Church. They flow into mysticism. Pastoral discerning is not only Christological, it is Christocentric. It aspires from the quiver of the Church due to the growth of the body of Christ to the path to its culmination in the heavenly liturgy. It flows into asceticism.

In her ongoing discernment, the Church can also come to see that certain customs not directly connected to the heart of the Gospel, even some which have deep historical roots, are no longer properly understood and appreciated. Some of these customs may be beautiful, but they no longer serve as means of communicating the Gospel. We should not be afraid to re-examine them. ${ }^{57}$

When the Pope speaks of pastoral discerning, he touches on the Church as the one who discerns. The starting point for pastoral discerning is not criteria for the activity of discerning or for the object discerned, but criteria for the discerning person. Here he speaks as one who wants to lead to the very nature of discerning: "I am a sinner on whom the Lord has looked down.. ${ }^{58}$ Pope Francis explains the ability to discern with the picture The Calling of St Matthew by Caravaggio. In the picture Jesus finger is pointing at Matthew, who finds it hard to stop looking at the money in front of him. That was also Francis's attitude characterizing his acceptation of election: "I am a sinner but by the mercy of our Lord Jesus Christ I trust and with a penitent spirit accept." This view is crucial and brings the servant of the Gospel to leave his own darkness and enter a new darkness of the night with the one who descends into human darkness and the underworld, in order to call out Easter's "Adam, where are you!". Discerning means not only to look at the approaching signs. It means adhering to the one who will lead me through life. The people of God need not only those who can read the signs of the times, but also those who accompany those buffeted between hope and anxiety and do not desert them. Discerning does not serve exclusively knowledge, but closeness, union, embrace. Here Bergoglio does not deny his Ignatian charisma:

Ignatius saw Christ with the cross on his shoulders and next to him the Father telling him: 'I want you to take this one for your servant.' Then Jesus turned to Ignatius and told him: 'I want you to serve us.' He was promised divine protection for the future order as well. ${ }^{59}$

Discerning seeks nothing but to find a practical form of how a Christian can find God in the manner of using things. Love arouses imagination, which orients human feeling.

57 FRANCIS, Evangelii gaudium, 43. Further only EG and section number.

58 U mne je vždy otevřeno. Papež František v rozhovoru s Antoniem Spadarem SJ, Praha: Paulínky, 2013, p. 20.

59 IGNATIUS OF LOYOLA, Souborné dílo, Olomouc: Refugium, 2005, p. 288. 
But this conviction has to be sustained by our own constantly renewed experience of savouring Christ's friendship and his message. It is impossible to persevere in a fervent evangelization unless we are convinced from personal experience that it is not the same thing to have known Jesus as not to have known him, not the same thing to walk with him as to walk blindly, not the same thing to hear his word as not to know it, and not the same thing to contemplate him, to worship him, to find our peace in him, as not to. ${ }^{60}$

The aim of discerning is not to discern precisely, but to allow the moral conscience and awareness to be stimulated by love of Christ in the direction in which one tends, even though he must make a maximal effort to do good and avoid evil. It is not indeterminate, for the very tending to spirituality can be nothing but a form of "a spiritual consumerism tailored to one's own unhealthy individualism". ${ }^{11}$ Similarly activism of service to the other can be merely an alibi, since it is necessary to distinguish "the authentic option for the poor from any other ideology". ${ }^{62}$ Discerning is the inner attitude of desire to help the other, be close to him and at the same time learn "to remove our sandals before the sacred ground of the other" ${ }^{63}$ In discerning man dies to himself; the reason for the decision is due to something deeper than my view of the matter: "If we are to share our lives with others and generously give of ourselves, we also have to realize that every person is worthy of our giving. (...) Every human being is the object of God's infinite tenderness, and he himself is present in their lives." ${ }^{164}$ Discerning means to enter inside, to share intimacy by communication born by the presence of the Spirit. "One who accompanies others has to realize that each person's situation before God and their life in grace are mysteries which no one can fully know from without." ${ }^{\prime 65}$ Discerning crosses habitual borders because it extends our perspective by the present Lord's view of the "injured world". We live through daily experiences with people, and through discerning we are further prepared to open ourselves up to the fact that other seekers also "have their highest expression and source in God" ${ }^{66}$ Discerning carries in it a perception of the gradual maturation of time. "Reaching a level of maturity where individuals can make truly free and responsible decisions calls for much time and patience." ${ }^{\prime 67}$ Time is not a reality that is foreign to God, simply because God wanted to reveal himself and save us in history, in time. The meaning of time, temporality, in the atmosphere of divine self-revelation, i.e., revealing the mystery of God and His concrete love. He represents the type of one who discerns. He is a restless spirit, hesitant and never satisfied. He learns to link his restlessness, but also has a delicate and refined sensitivity with the ability to adopt decisions. The one who discerns carries great desires inside. When difficulties arise, they stimulate him to further activity. Discerning is a manifestation of true faith encompassing a deep desire to change the world.

In the eyes of Pope Francis, discerning is an instrument of personal engagement, struggle and life-long effort on the path of life whose meaning opens up to use every day from its goal. From its orientation we can sense the path, the direction we must go. The planting is evaluated according to what harvest it brings. By discerning man changes his likeness: before discerning he "bears 
the likeness of the man who was made from dust" (1 Cor 15: 49a). Due to discerning "we will also bear the likeness of the man from heaven" (1 Cor 15: 49b). The first man is "a body decaying" (1 Cor 15: 42), the second man in his body becomes the body of Christ through discerning, by which he grows into Christ with his feeling, perception and intimacy (cf. Phil 2: 2), and therefore receives "a body that cannot decay" (1 Cor 15: 42). So the Christian becomes a sign of the time, with his body, with the human lot assigned to him and freely accepted by him he participates in the transformation of the body of Jesus Christ who accepted the human lot. Running away from death, Jonah's syndrome, changes into Jonah's sign by the concrete, irrevocable and unmerited grace of bodily resurrection. And we will be given no other sign than the sign of Jonah.

In the world and in the life of nature, which are a closed world and life, everything is accidental, without interconnection, having no meaning; man, in case he is merely a part of nature, is devoid of meaning and depth and his natural life is stripped of the succession meanings. But man as an image of divine being, that means as a symbol of divinity, has a precise and absolute meaning. Consciousness directed to the divine world, however, opens up an inner concatenation of meaning. It contains pointers to another world. This consciousness is free and assigns meaning to the apparent emptiness of the natural world. It is impossible to prove the existence of meaning in universal life; it cannot be extracted rationally by induction from the natural world. The directedness of natural processes appears problematic. Meaning cannot be discovered otherwise than that which we have experienced in spiritual experience, other than that which we have directed to the spiritual world. We cannot demonstrate it in any other way than by life pervaded by meaning, symbolic consciousness that signifies it, connects and gives it meaning. ${ }^{68}$

By discerning we receive meaning as an unmerited gift, which is a supreme expression of freedom. We 'give up' freedom that would determine meaning apart from relationality. By discerning we co-sacrifice ourselves. Because on the Cross we recognize in the Crucified the proper meaning of human dignity, which does not consist in loving, but in being loved. Only this newness of life opens up the path to observing, e.g., that "there are heavenly bodies and earthly bodies, but the splendour of those in heaven is of one kind, and that of those on earth is of another. One kind of splendour belongs to the sun, another to the moon, and still another to the stars. In fact, one star differs from another star in splendour" (1 Cor 15: 40-41). The daily dying to oneself are what raises the mast of Christ's Cross in the Church as the only sign in which victory is certain. What is today entrusted to the Church as a sign of the times is the human body destined to transformation.

\section{From Church Scrutinizing the Signs of the Times (GS 4) to Church Discerning (EG 43)}

\section{Abstract:}

The paper reacts to the experienced need to embody faith in life, which implies also the need to interconnect theology and pastoral care. This requirement was loudly stated at the Second Vatican Council, which invites the Christian to scrutinize the signs of the times. The Church can be perceived as a great ship that is to provide security for humanity and bring salvation. The 
contemporary human being sails the sea of the world buffeted between hope and anxiety. Precisely this buffeting can be viewed as a sign of the times. But it is apparently insufficient to stop at it. Scrutinizing signs of the times is linked to a perceptiveness for the presence of Creator-Father in the created world. If from there we then move to a pastoral discernment in the Ignatian sense of the word, the presence of the Son of God as beginning and culmination of the salvation poured out into the entire body of Christ, i.e., the Church, becomes central. Central significance is then attained by the post-Easter presence of Christ in the Church as an experienced and spiritual fertility developing the unity of the divine and the human. The author shows that precisely through discernment, to which Pope Francis is newly inviting us, the Church can guide the person to hope.

Keywords: pastoral care, signs of the times, aggiornamento, discernment, hope, anxiety, human, Church

\section{Contact}

\section{Prof. Dr. Pavel Ambros SJ}

Palacký University in Olomouc

Sts Cyril and Methodius Faculty of Theology, Department of Pastoral and Spiritual Theology Univerzitní 244/22, 77111 Olomouc

pavel.ambros@upol.cz 